TIS FILE

RECORD COPY

\title{
VAPORIZATION OF SEMI-VOLATILE \\ COMPONENTS FROM \\ SAVANNAH RIVER PLANT WASTE GLASS
}

G. W. WILDS

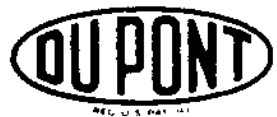

SAVANNAH RIVER LABORATORY AIKEN, SOUTH CAROLINA 29801 
This report was prepared as an account of work sponsored by the United States Government. Neither the United States nor the United States Department of Energy, nor any of their contractors, subcontractors, or their employees, makes any warranty, express or implied or assumes any legal liability or responsibility for the accuracy, completeness or usefulness of any information, apparatus, product or process disclosed, or represents that its use would not infringe privately owned rights.

Prifited in the United States of America

Avalable from

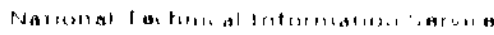

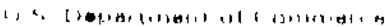

5285 Port Hoyal Road

Springtiold, Virginia 22161

Price. Printed Copy $\$ 4$. UU; Microtiche $\$ 3 . U 4$ 
Distribution Category UC-4

\section{VAPORIZATION OF SEMI-VOLATILE COMPONENTS FROM SAVANNAH RIVER PLANT WASTE GLASS}

by

G. W. WILDS

Approved by

M. L. Hyder, Research Manager

Separations Chemistry Division

Publication Date: August 1978

E. I. DU PONT DE NEMOURS AND COMPANY SAVANNAH RIVER LABORATORY AIKEN, SOUTH CAROLINA 29801 PREPARED FOR THE U. S. DEPARTMENT OF ENERGY UNDER CONTRACT AT(07-2)-1 


\section{ABSTRACT}

Sodium and boric oxides account for $\sim 90 \%$ of the semi-volatile off-gases that are generated during vitrification of Savannah River Plant waste. The two oxides volatilize as the thermally stable compound sodium metaborate, $\mathrm{Na}_{2} \mathrm{O} \cdot \mathrm{B}_{2} \mathrm{O}_{3}$. The quantity of semi-volatiles increases with increases in (1) the temperature of the melt, (2) the time of vitrification, (3) the surface area of the melt, and (4) the sodium content of the glass-forming mixture. The amounts of semi-volatiles evolved in three hours varied from 1.5 to $9.0 \mathrm{mg}$ per $\mathrm{cm}^{2}$ of melt surface. Values between $3.5-4.0 \mathrm{mg} / \mathrm{cm}^{2}$ were typical for normal melting conditions and compositions

Cesium oxide volatility averaged $0.11 \mathrm{mg} / \mathrm{cm}^{2}$ from samples that contained $0.06 \mathrm{wt} \% \mathrm{Cs}_{2} \mathrm{O}$. Volatilities ranged from 0.09 to $0.2 \mathrm{mg} / \mathrm{cm}^{2}$. Volatility of $\mathrm{Cs}_{2} 0$ was not significantly suppressed when $\mathrm{TiO}_{2}$ was added to the glass melt. Cesium volatility was unaffected when Cs was added to the melt as Cs-loaded zeolite rather than a $\mathrm{Cs}_{2} \mathrm{CO}_{3}$ solution. Over a range of $0.03-0.09 \mathrm{wt} \%$ $\mathrm{Cs}_{2} \mathrm{O}$ in the melt, volatility of $\mathrm{Cs}_{2} \mathrm{O}$ increased when the $\mathrm{Cs}$ content of the melt increased.

Lithium volatility was low and was unaffected by changes in melting conditions or melt composition. Lithium, like sodium, volatilized from borosilicate melts as the metaborate, $\mathrm{Li}_{2} \mathrm{O} \cdot \mathrm{B}_{2} \mathrm{O}_{3}$. 


\section{CONTENTS}

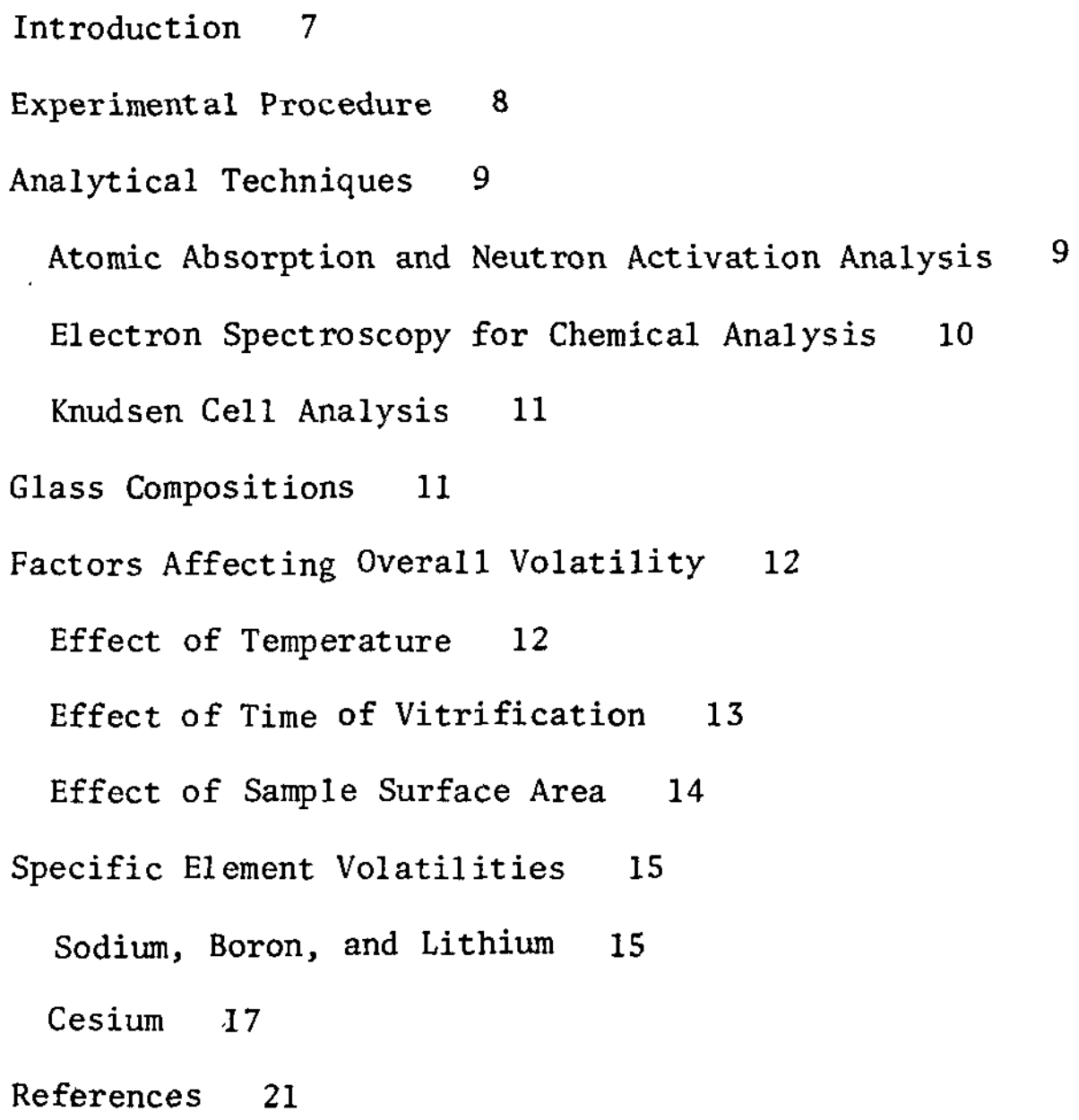




\section{LIST OF TABLES}

1 Frit Compositions, wt \% 11

2 Composition of Simulated Calcined Sludge 12

3 Effect of Temperature on Volatility 13

4 Increase in Volatility with Increase in Time of Melting 13

5 Thickness of Melt Required to Produce Different Amounts of Semi-Volatiles 14 .

6 Effect of Total Sample Weight on Weight Loss 15

7 Volatility of $\mathrm{Na}, \mathrm{Li}$, and B From Frit 21 Glass Melts 16

8 Volatility of $\mathrm{Na}$ and $\mathrm{B}$ From Frit 18 Glass Melts 16

9 Elemental Ratios at Surfaces of Glass Melts as Measured by ESCA 17

10 Effect of Addition of $\mathrm{TiO}_{2}$ on Cesium Volatility 20

11 Effect of Form of Addition on Cesium Volatility 20

12 Effect of $\mathrm{Cs}_{2} \mathrm{O}$ Concentration on Cesium Volatility 20 


\section{LIST OF FIGURES}

$1 \quad$ Volatility Apparatus 8

2 Effect of $\mathrm{N}_{2}$ Sweep Rate on Weight Loss 9

3 Comparison of $\mathrm{Na}_{2} \mathrm{O}$ Volatility Measured by NAA and AA 10

4 Volatility of $\mathrm{Na}_{2} \mathrm{O} \cdot \mathrm{B}_{2} \mathrm{O}_{3}$ at Various $\mathrm{Na}_{2} \mathrm{O}$ Concentrations 18 


\section{VAPORIZATION OF SEMI-VOLATILE COMPONENTS FROM SAVANNAH RIVER PLANT WASTE GLASS}

\section{INTRODUCTION}

Radioactive high-level waste that is stored at Savannah River Plant (SRP) consists of an alkaline supernate, crystallized salts, and a precipitated sludge. Most of the ${ }^{137} \mathrm{Cs}$ and small amounts of other radionuclides are contained in the supernate and soluble salt fractions of the waste. Nearly all of the ${ }^{90} \mathrm{Sr}$ as well as other hydrolyzable radioactive elements are precipitated with the sludge. In the conceptual process of solidification of SRP waste, the cesium is concentrated and added to the sludge, which is then incorporated into a borosilicate glass matrix by spray calcination and electric melting. Components of both the waste sludge and the borosilicate glass frit will volatilize at the high temperature used for fixation of waste into g1ass. Therefore, Savannah River Laboratory (SRL) initiated a program to determine the types and quantities of species that vaporize from the calciner/melter system. These studies provide some of the basic data required to design an off-gas clean-up system for a proposed Defense Waste Processing Facility (DWPF). This report details the laboratory studies of the vaporization of the semi-volatile components $\mathrm{Na}, \mathrm{Cs}, \mathrm{Li}$, and $\mathrm{B}$ from glass melts. The chemical form in which each species volatilizes, the mechanisms of vaporization, as well as some of the factors that determine volatility are discussed. Volatility of radionuclides from SRP waste glass was reported previously by Kelley. ${ }^{1}$ A future report will describe the volatility of $\mathrm{Ru}$ and will discuss trapping methods for vapors of $\mathrm{Ru}$ and $\mathrm{Hg}$.

The principle source of sodium, lithium, and boron in SRP waste is the glass-forming frit, though some sodium, and to a much lesser extent, boron are present in the waste sludge. ${ }^{2,3}$ Cesium originates from the waste supernate and is introduced into the glass as the calcined eluate from the ion exchange (Dowex) process for decontamination of supernate. ${ }^{3}$ Cesium can also be sorbed onto zeolite and the cesium-loaded zeolite added directly to the melt.

For this study, all glasses were prepared from a nonradioactive mixture of metal oxides and a premelted borosilicate glass frit. The nonradioactive metal oxides simulated calcined waste. Frits 21 and 18, two high alkali frits, were used in all studies. 


\section{EXPERIMENTAL. PROCEDURE}

The apparatus used to measure glass volatility is shown schematically in Figure 1. The crucible, collection tube and 1id assembly, and hypodermic tubing were fabricated from platinum. The transfer line from the collection tube to the scrubber was stainless steel and the scrubber glass. Volatility of the melt was determined by mixing the required proportions of glass frit/ simulated sludge in the crucible, which was then introduced into the furnace. The furnace was heated to the melting temperature prior to introduction of the sample. Normal melting conditions consisted of holding a $2 \mathrm{~g}$ sample at $1150^{\circ} \mathrm{C}$ for three hours. The melt was blanketed with $\mathrm{N}_{2}$, introduced through the hypodermic tubing. A vacuum was applied to the scrubber to ensure that all volatilized species were removed from the reaction crucible.

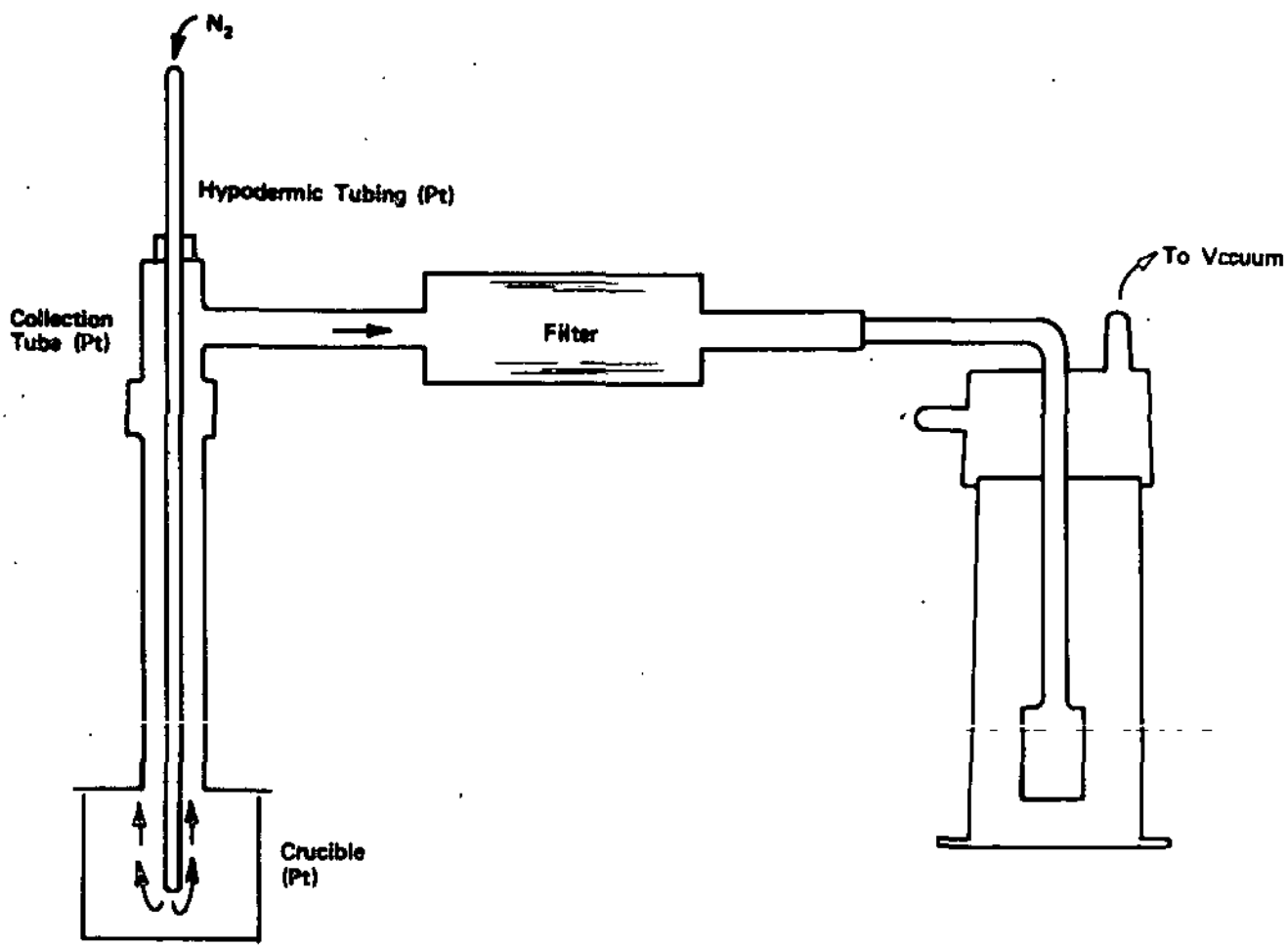

FIGURE 1. Volatility Apparatus

The semi-volatiles condensed at the top of the collection tube, on the hypodermic tubing, in the transfer lines, and on the surface of the filter. Less than $1 \%$ of the semi-volatiles penetrated the filter and collected in the scrubber. The condensed gases were washed from the various parts of the apparatus and analyzed for $\mathrm{Na}, \mathrm{B}, \mathrm{Li}$ and $\mathrm{Cs}$ by atomic absorption 
spectrophotometry (AA) or neutron activation analysis (NAA). A $0.1 \mathrm{M} \mathrm{HNO}_{3}$ solution was used for washing out the apparatus and as a scrubber solution.

In preliminary experiments, the quantity of off-gases depended on the rate at which the $\mathrm{N}_{2}$ atmosphere was swept across the melt surface. The quantity of off-gases initially increased with increased atmosphere sweep rate, and then reached a plateau at a flow rate of $\sim 500 \mathrm{~mL} / \mathrm{min}$ (Fig. 2). A flow rate of $750 \mathrm{~mL} / \mathrm{min}$ was used in most of the experiments reported here. This flow rate is well within the plateau region of the curve and assures reproducible results. The dependence of volatility on flow rate was observed by several other workers ${ }^{4,5}$ and is explained by Barlow ${ }^{4}$ in terms of diffusion through the melt and evaporation from the surface of the melt.

The value used for the surface area was the area of the circle formed by the melt line of the molten glass. This value was used since the crucible was not a right cylinder and the surface area depended on the height of the melt in the crucible. For a $2 \mathrm{~g}$ sample the surface area calculated by this method was $4.7 \mathrm{~cm}^{2}$.

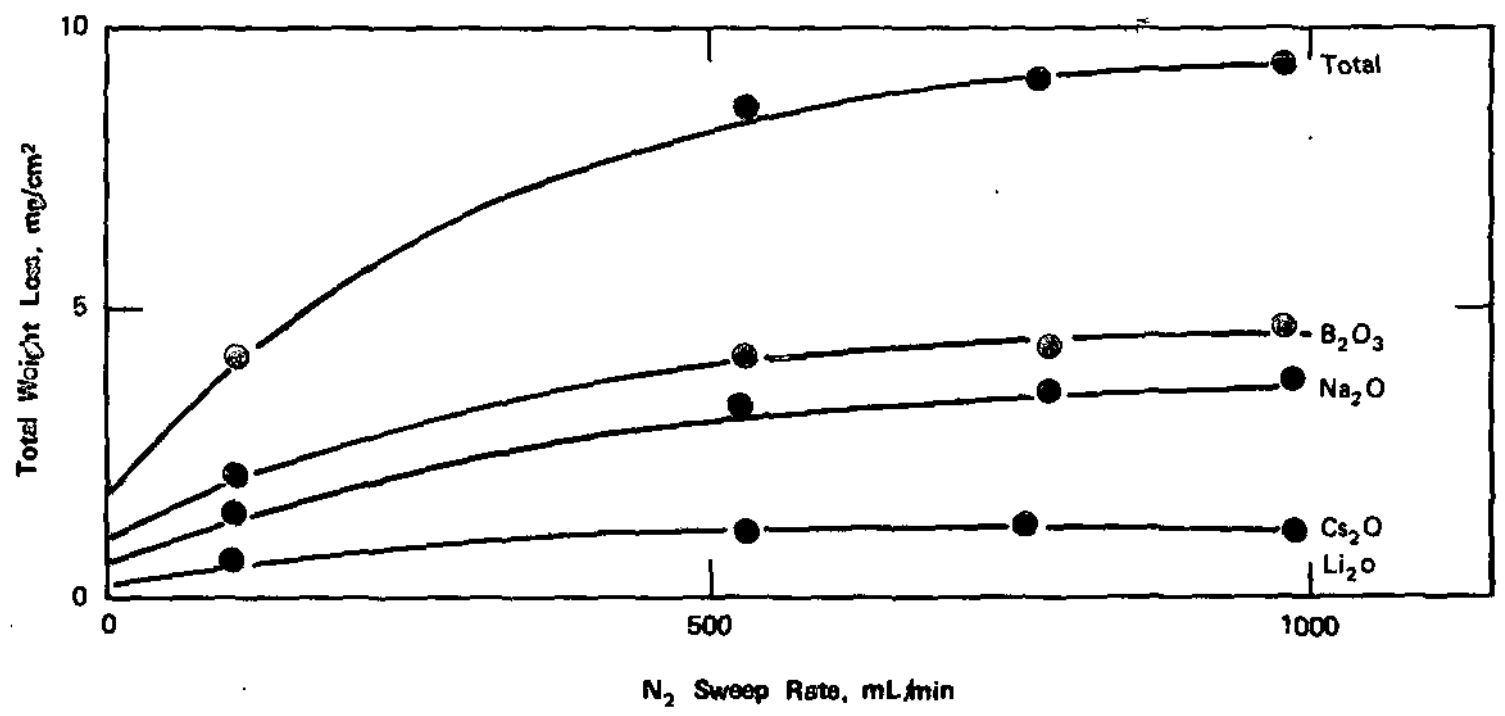

FIGURE 2. Effect of $\mathrm{N}_{2}$ Sweep Rate on Weight Loss $60 / 40$ Frit/Sludge -3 Hours at $1150^{\circ} \mathrm{C}$

\section{ANALYTICAL TECHNIQUES}

Atomic Absorption (AA) and Neutron Activation Analys is (NAA)

Analysis of the condensate from the melting apparatus by AA or NAA was the major analytical technique used in these experiments. 
Samples were analyzed for the metals $\mathrm{Na}, \mathrm{Li}, \mathrm{B}$, and $\mathrm{Cs}$. Atomic absorption was used for all metals; NAA was used in some cases to analyze for $\mathrm{Na}$ and $\mathrm{Cs}$. The results for samples analyzed by both techniques were in good agreement (Fig. 3). Boron presented a particular problem because it could not be determined with NAA, and the detection 1 imit of $A A$ for boron analysis was quite high. When B was present in quantities below the detection limit, B was assigned a value equal to the detection limit. Since this problem occurred in only about $2 \%$ of the cases, the few times that B was assigned a value had no influence on the conclusions drawn from the data.

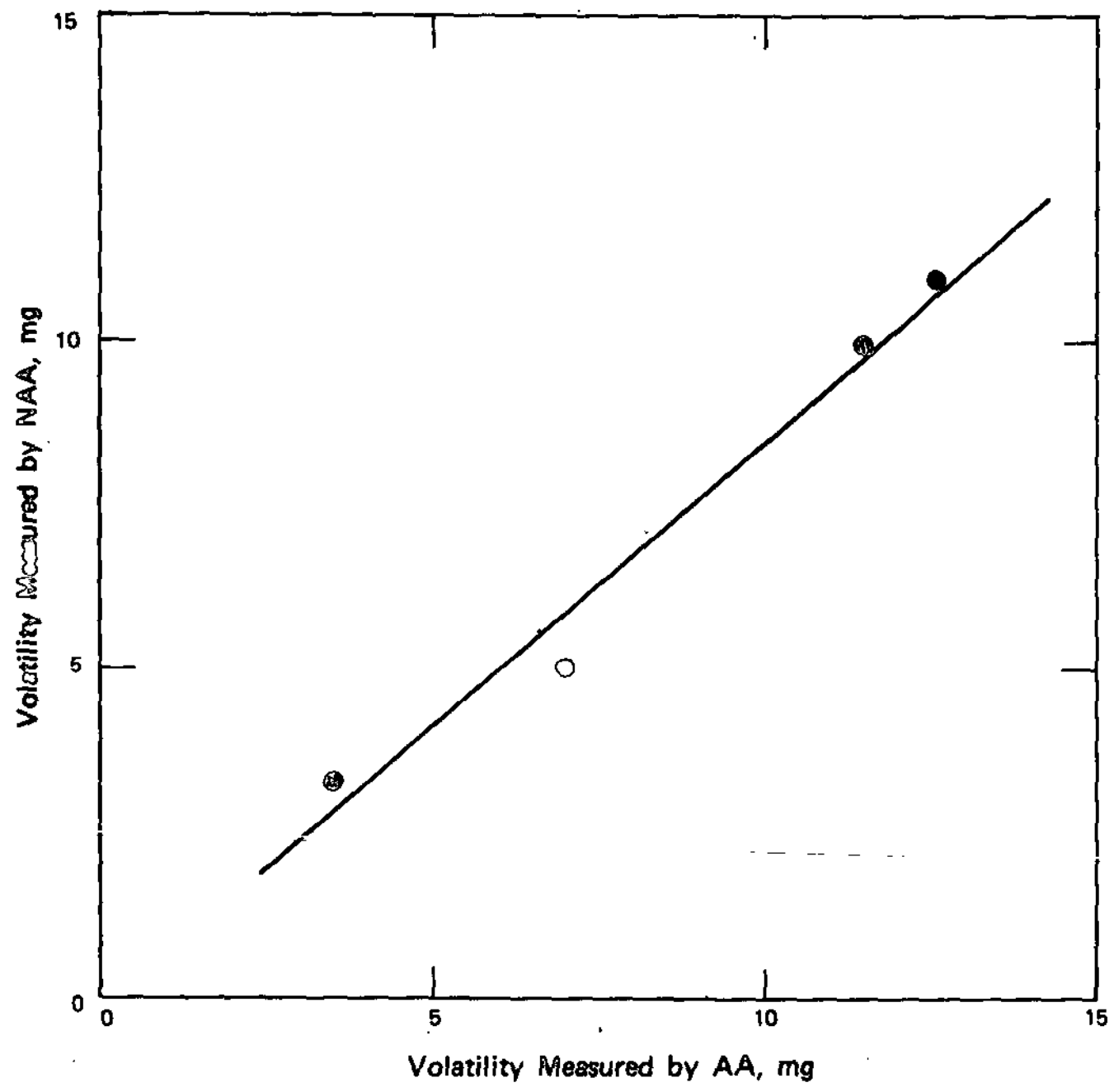

FIGURE 3. Comparison of $\mathrm{Na}_{2} \mathrm{O}$ Volatility Measured by NAA and $A A$

\section{Electron Spectroscopy For Chemical Analysis (ESCA)}

The surfaces of some melts were studied by electron spectroscopy for chemical analysis (ESCA). The surface of the samples was analyzed to determine the degree of sodium depletion by 
measuring the $\mathrm{Na} / \mathrm{Si}$ ratio. No attempt was made to measure $\mathrm{Na} / \mathrm{Si}$ ratios at depths greater than a few microns.

\section{Knudsen Cel1 Analysis}

The composition of the vapors evolved from a sample of glass-forming frit and a sample of frit/simulated sludge was determined by a Knudsen cell analysis. The sample of glass was remelted in a Knudsen cell-mass spectrometer, and the generated vapors were analyzed. At melt temperatures of $800,1000,1100$, and $1200^{\circ} \mathrm{C}$, the composition of the vapors was determined.

\section{GLASS COMPOSITIONS}

Table 1 lists the two borosilicate glass-forming frits used in these studies. Frit 21 is identical to Frit 18 except that 4 wt $\% \mathrm{Li}$ has replaced some of the $\mathrm{Na}$. Frit 21 reduces the viscosity of the glass during both melting and pouring operations. The high $\mathrm{Fe}$, high $\mathrm{Al}$, and average simulated calcined sludges were prepared by mixing quantities of the dried metal oxides in the proportions required to give the compositions shown in Table 2 . The compositions are based on actual analyses of SRP waste sludge ${ }^{2,3}$ and represent waste tanks with typically high Fe concentrations, Al concentrations, and an overall average concentration for all tanks sampled.

The cesium content of SRP waste glass was calculated to be 0.06 wt $\%\left(\mathrm{Cs}_{2} \mathrm{O}\right)$. Since this small amount of solid could not be added to the $2 \mathrm{~g}$ samples, $\mathrm{Cs}$ was added either by adsorption of the Cs onto zeolite or by aliquots of $\mathrm{a} \mathrm{Cs}_{2} \mathrm{CO}_{3}$ solution to the glass-forming mixture. When $\mathrm{Cs}$ was added from solution, the sample was dried to remove excess water before it was placed in the melting furnace. This prevented entrance of particulates into the vapor stream by entrainment in water vapor.

TABLE 1

Frit Compositions (wt \%)

\begin{tabular}{|c|c|c|}
\hline Component & Frit 21 & Frit 18 \\
\hline $\mathrm{SiO}_{2}$ & 52.5 & 52.5 \\
\hline $\mathrm{Na}_{2} \mathrm{O}$ & 18.2 & 22.2 \\
\hline $\mathrm{B}_{2} \mathrm{O}_{3}$ & 10.0 & 10.0 \\
\hline $\mathrm{TiO}_{2}$ & 10.0 & 10.0 \\
\hline $\mathrm{CaO}$ & 5.0 & 5.0 \\
\hline $\mathrm{Li}_{2} \mathrm{O}$ & 4.0 & - \\
\hline
\end{tabular}


TABLE 2

Composition of Simulated Calcined Sludges

\begin{tabular}{|c|c|c|c|c|}
\hline \multirow[b]{2}{*}{ Metal Oxide } & \multicolumn{3}{|c|}{$\begin{array}{c}\text { Amount of Metal oxide } \\
\text { in Sludge, wt \% }\end{array}$} & \multirow[b]{2}{*}{ Sludge $A$} \\
\hline & High Fe & High Al & Average & \\
\hline $\mathrm{Fe}_{2} \mathrm{O}_{3}$ & 61.4 & 6.0 & 31.0 & 41.7 \\
\hline $\mathrm{Al}_{2} \mathrm{O}_{3}$ & 5.6 & 86.3 & 35.0 & 24.8 \\
\hline $\mathrm{MnO}_{2}$ & 4.1 & 4.9 & 10.0 & 11.3 \\
\hline $\mathrm{U}_{3} \mathrm{O}_{8}$ & 14.2 & 1.5 & 10.0 & -- \\
\hline $\mathrm{CaO}$ & 4.2 & 0.4 & 3.0 & 3.9 \\
\hline $\mathrm{NiO}$ & 10.5 & 0.9 & 5.0 & 4.7 \\
\hline $\mathrm{Na}_{2} \mathrm{O}$ & -- & -- & -- & 10.1 \\
\hline $\mathrm{SiO}_{2}$ & -- & -- & -- & 2.3 \\
\hline
\end{tabular}

\section{FACTORS AFFECTING OVERALL VOLATILITY}

Three factors significantly affect the overall volatility from borosilicate glass melts. The volume of semi-volatile off-gases increases with (1) increases in the temperature of vitrification, (2) the time of vitrification and (3) the surface area of the melt.

\section{Effect of Temperature}

No appreciable amount of semi-volatiles was evolved at temperatures below $900^{\circ} \mathrm{C}$. Volatility was determined by measuring weight losses from $2 \mathrm{~g}$ samples of $60 \%$ Frit $21 / 40 \%$ Sludge A. Vitrification was carried out at temperatures of $9 \overline{0} \overline{0}, \overline{1} \overline{0} \overline{0}$, and $1150^{\circ} \mathrm{C}$ for three hours. Vitrification was done under static conditions, i.e., without sweeping a stream of $\mathrm{N}_{2}$ across the surface of the melt. This resulted in relatively low total weight losses. The effect of temperature on volatility is summarized in Table 3. Weight losses after 3 hours at $900^{\circ} \mathrm{C}$ show negligible volatility, with a total weight loss of $0.02 \mathrm{mg} / \mathrm{cm}^{2}$. This small weight loss is probably from the volatilization of $\mathrm{Cs}_{2} \mathrm{O}$. Total volatility increased at $1050^{\circ} \mathrm{C}$ to $0.9 \mathrm{mg} / \mathrm{cm}^{2}$ and at $1150^{\circ} \mathrm{C}$ to $1.6 \mathrm{mg} / \mathrm{cm}^{2}$. The $10 \mathrm{w}$ volatility at $900^{\circ} \mathrm{C}$ was also observed when a $\mathrm{N}_{2}$ stream was swept across the melt surface. This confirms that no semi-volatiles vaporized at temperatures below $900^{\circ} \mathrm{C}$. 
TABLE 3

Effect of Temperature on Volatility



$\begin{array}{lllll}900 & 0.0 & 0.01 & 0.01 & 0.02\end{array}$

$\begin{array}{lllll}1050 & 0.4 & 0.5 & 0.8 & 1.0\end{array}$

$\begin{array}{lllll}1150 & 0.6 & 0.8 & 1.3 & 1.6\end{array}$

Glass mixture: $60: 40$ mixture of Frit 21/Sludge

A; Run under static conditions

Effect of Time of Vitrification

The evolution of off-gases increased when the time of vitrification was increased. Weight losses from samples that contained $60 \%$ Frit $21 / 40 \%$ Sludge A were measured for times ranging from 30 minutes to 3 hours (Table 4). No air flow across the surface was used in the initial series of tests. The cumulative amount of off-gas increased with increased vitrification time at both 1050 and $1150^{\circ} \mathrm{C}$. Total volatilities for the $1150^{\circ} \mathrm{C}$ temperature ranged from $0.6 \mathrm{mg} / \mathrm{cm}^{2}$ after 30 minutes to $1.6 \mathrm{mg} / \mathrm{cm}^{2}$ after 3 hours. Comparable values for $1050^{\circ} \mathrm{C}$ were $0.4 \mathrm{mg} / \mathrm{cm}^{2}$ after 30 minutes and $1.0 \mathrm{mg} / \mathrm{cm}^{2}$ after 3 hours. In a second series of tests, $\mathrm{N}_{2}$ was swept across the surface of the melt at $750 \mathrm{~mL} / \mathrm{min}$, increasing the volatility to $3.5-4.0 \mathrm{mg} / \mathrm{cm}^{2}$ after 3 hours and $8.5-9.0$ $\mathrm{mg} / \mathrm{cm}^{2}$ after 5 hours.

TABLE 4

Increase in Volatility With Increase in Time of Melting

\begin{tabular}{|c|c|c|}
\hline Temp. ${ }^{\circ} \mathrm{C}$ & Time of Melting, hr & $\begin{array}{l}\text { Cumulative } \\
\text { Weight Loss, } \mathrm{mg} / \mathrm{cm}^{2}\end{array}$ \\
\hline 1150 & 0.5 & 0.6 \\
\hline 11.50 & 1 & 0.8 \\
\hline 1150 & 2 & 1.3 \\
\hline 1150 & 3 & 1.6 \\
\hline 1150 & 4 & 2.0 \\
\hline 1050 & 0.5 & 0.4 \\
\hline 1050 & 1 & 0.5 \\
\hline 1050 & 2 & 0.8 \\
\hline 1050 & 3 & 1.0 \\
\hline
\end{tabular}

Glass mixture: $60 / 40$ mixture of Frit 21/SIudge A; Run under static conditions 


\section{Effect of Sample Surface Area}

Volatilization occurs at the surface of the melt and is independent of the melt's volume. Both Barlow ${ }^{4}$ and Walmsley ${ }^{5}$ report a similar effect of surface area on glass volatility. For the present study, samples with nominal weights of 2,5 and 9 grams were vitrified and the weight loss measured. The wt \% ratio of Frit $21 /$ SI udge $A$ was held constant at $60 / 40$. The failure of weight loss to vary with changes in sample weight and volume indicated that only a small surface portion of the sample contributes to volatility of semi-volatiles. This is consistent with a diffusion mechanism of volatility discussed by Barlow. ${ }^{4}$ Analysis of off-gases shows that the volatile oxides in a small layer ( $\sim-3 \mathrm{~mm}$ thick) at the surface could completely account for the quantity of gases volatilized. Table 5 shows that the thickness of the 1 ayer that produces various amounts of semi-volatiles is independent of the weight of the melt. A comparison of the data in Table 6 demonstrates that semi-volatiles vaporize by diffusion from the surface while true volatiles (e.g. $\mathrm{H}_{2} \mathrm{O}$ vapor) depend on the volume of the sample. When the 2,5 and 9 gram samples were heated to $900^{\circ} \mathrm{C}$, the weight loss of each sample was proportional to the volume of the sample. This was expected since the components which volatilize at $900^{\circ} \mathrm{C}$ are not surface-area 1 imited. When the same samples were melted at $1150^{\circ} \mathrm{C}$, the semi-volatile off-gases produced were proportional to the surface area and not to the volume or weight of the melt.

\section{TABLE 5}

Thickness of Melt Required to Produce Different. Amounts of Semi-Volatiles

Total Weight Loss, $\mathrm{mg} / \mathrm{cm}^{2}$
4.3
8.4
8.6
9.1

Thickness of Layer, $\mathrm{cm}$

$\overline{\mathrm{Na}_{2} \mathrm{O}} \quad \mathrm{B}_{2} \mathrm{O}_{3} \quad \mathrm{Li}_{2} \mathrm{O}$

$0.8 \quad 1.2 \quad 0.06$

$\begin{array}{lll}0.7 & 2.0 & 0.2\end{array}$

$\begin{array}{lll}0.9 & 2.5 & 0.2\end{array}$

$\begin{array}{lll}1.1 & 2.6 & 0.2\end{array}$ 
TABLE 6

Effect of Total Sample Weight on Weight Loss ${ }^{a}$

\begin{tabular}{llllll} 
Sample & $\begin{array}{l}\text { Weight, } \\
g\end{array}$ & $\begin{array}{l}\text { Relative } \\
\text { Weight }\end{array}$ & \multicolumn{2}{l}{$\begin{array}{l}\text { Relative Loss } \\
\text { on Melting }\end{array}$} & $\begin{array}{l}\text { Relative Loss on } \\
\text { Heating to } 900^{\circ} \mathrm{C}\end{array}$ \\
$31-3$ & 8.7329 & 4.3 & 1.2 & 0.3 & 4.3 \\
$31-2$ & 5.0527 & 2.5 & 1.3 & 0.5 & 2.1 \\
$31-1$ & 2.0089 & 1 & 1 & 1 & 1
\end{tabular}

\footnotetext{
a. Sample heated at $1150^{\circ} \mathrm{C}$ for 3 hours.

Sample composition $60 / 40$, Frit $21 /$ simulated sludge.

b. mg volatitized/total gram of sample
}

\section{SPECIFIC ELEMENT VOLATILITIES}

The volatility of specific elements was determined by a factorial experiment which utilized two frit types (Frits 21 and 18), three sludge types (high alumina, high iron and average) and three sludge loadings $(25,35$ and 45 wt \%). The volatility of each element was determined by collecting the off-gases and analyzing for the metals by the techniques discussed in the section on analytical procedures. Also, two samples were analyzed by a Knudsen ce11 to determine which species occurred in the vapor phase.

Sodium, Boron, and Lithium

Volatilities of $\mathrm{Na}, \mathrm{Li}$, and $\mathrm{B}$ are discussed together since these species vaporized from the melt as alkali borates. The thermally stable compound sodium metaborate, $\mathrm{Na}_{2} \mathrm{O} \cdot \mathrm{B}_{2} \mathrm{O}_{3}$ comprised $290 \%$ of the off-gases when glasses were vaporized. Small quantities of $\mathrm{LiBO}{ }_{2}, \mathrm{Li} \cdot \mathrm{NaBO}_{2}, \mathrm{Na}_{2} \mathrm{BO}_{2}$ and $\mathrm{B}_{2} \mathrm{O}_{3}$ were also detected in the vapor. The species in the vapor were determined by the Knudsen-cell mass spectrometer analysis. In the condensed phase measurements, the species that volatilized were determined from the molar ratios of $\mathrm{Na} / \mathrm{B}$ and $(\mathrm{Li}+\mathrm{Na}) / \mathrm{B}$ in the condensate. $\mathrm{A}$ ratio of one would indicate the metaborate, a ratio of two would indicate the diborate and a mixture of the two compounds would be indicated by a ratio between one and two. The ratio of $\mathrm{Na} / \mathrm{B}$ should be less than one when the melt contains lithium, since only part of the boron is associated with $\mathrm{Na}$; the rest forming a lithium borate. The ratio of $(\mathrm{Li}+\mathrm{Na}) / \mathrm{B}$ would equal one, 
however, if $\mathrm{Li}_{2} \mathrm{O} \cdot \mathrm{B}_{2} \mathrm{O}_{3}$ and $\mathrm{Na}_{2} \mathrm{O} \cdot \mathrm{B}_{2} \mathrm{O}_{3}$ are the compounds that volatilize. A melt that contains $\mathrm{Na}$, but no $\mathrm{Li}$, should give a $\mathrm{Na} / \mathrm{B}$ ratio of 1 if $\mathrm{Na}_{2} \mathrm{O} \cdot \mathrm{B}_{2} \mathrm{O}_{3}$ is the vaporizing species. When Frit 21, which contained both $\mathrm{Na}$ and $\mathrm{Li}$ was used to prepare glasses (Table 7), the average molar ratio of $\mathrm{Na} / \mathrm{B}$ was 0.89 and of $(\mathrm{Na}+\mathrm{Li}) / \mathrm{B}$ was 1.02 . Off-gases from glasses prepared from Frit 18, a frit that contains no $\mathrm{Li}$, gave an average $\mathrm{Na} / \mathrm{B}$ ratio of 1.05 (Table 8). These three ratios show that the alkali and the boron volatilize as the compound $\mathrm{Na}_{2} \mathrm{O} \cdot \mathrm{B}_{2} \mathrm{O}_{3}$ and $\mathrm{Li}_{2} \mathrm{O} \cdot \mathrm{B}_{2} \mathrm{O}_{3}$. Solomin ${ }^{6}$ and Walmsley ${ }^{5}$ al so concluded that alkalis volatilize from borosilicate melts as thermally stable alkali borates.

TABLE 7

Volatility of $\mathrm{Na}, \mathrm{Li}$, and B From Frit 21 Glass Melts

\begin{tabular}{|c|c|c|c|c|c|c|}
\hline \multirow{3}{*}{$\begin{array}{l}\text { code } \\
\text { 21-Avg-25 }\end{array}$} & \multirow{2}{*}{$\begin{array}{l}\mathrm{Na}_{2} \mathrm{O} \text { in Glas8, } \\
\text { mole \% }\end{array}$} & \multicolumn{3}{|c|}{ Volatility, $\mathrm{mg} / \mathrm{cm}^{2}$} & \multicolumn{2}{|l|}{ Molar Ratios } \\
\hline & & & & $\mathrm{B}_{2} \mathrm{O}_{3}$ & $\mathrm{Na}_{2} \mathrm{O} / \mathrm{B}_{2} \mathrm{O}_{3}$ & $\left(\mathrm{Na}_{2} \mathrm{O}+\mathrm{Li}_{2} \mathrm{O}\right) / \mathrm{B}_{2} \mathrm{O}_{3}$ \\
\hline & & 0.4 & 0.04 & 0.4 & 1 & 1.1 \\
\hline.-35 & & 0.4 & 0.05 & 0.5 & 1 & 1.1 \\
\hline-45 & 13.6 & 0.9 & 0.14 & 1.2 & 0.84 & 0.97 \\
\hline $21-\mathrm{Fe}-25$ & 17.1 & 1.4 & 0.20 & 1.5 & 0.99 & 1.1 \\
\hline-35 & 15.7 & 1.4 & 0.20 & 2.0 & 0.82 & 0.93 \\
\hline-45 & 14.2 & 0.7 & 0.13 & 1.0 & 0.83 & 0.98 \\
\hline $21-A 1-25$ & 16.1 & 1.3 & 0.16 & 2.0 & 0.74 & 0.84 \\
\hline-35 & 14.5 & 0.7 & 0.13 & 1.0 & 0.84 & 1.0 \\
\hline-45 & 12.6 & 0.5 & 0.08 & 0.5 & 1 & 1.2 \\
\hline & & & & age & 0.89 & 1.02 \\
\hline
\end{tabular}

TABLE 8

Volatility of $\mathrm{Na}$ and $\mathrm{B}$ From Frit 18 Glass Melts

\begin{tabular}{|c|c|c|c|c|c|}
\hline Code & $\begin{array}{l}\mathrm{Na}_{2} \mathrm{O} \text { ir } \\
\text { mole to }\end{array}$ & Glass, & $\begin{array}{l}\text { Volatility } \\
\text { NaLU }\end{array}$ & $\begin{array}{l}\mathrm{mg} / \mathrm{cm}^{2} \\
\bar{z}_{2} \bar{O}_{3}-\end{array}$ & $\begin{array}{l}\text { Molar Ratio } \\
-\ddot{H}_{2} a_{2} \hat{D}_{2} \hat{U}_{3}\end{array}$ \\
\hline $18-A v g-25$ & 21.2 & & 2.6 & 3.0 & 0.97 \\
\hline-35 & 19.4 & & 1.9 & 1.9 & 1.1 \\
\hline-45 & 17.1 & & 1.5 & 1.6 & 1.1 \\
\hline $18-\mathrm{Fe}-25$ & 21.6 & & 1.8 & 1.9 & 1.1 \\
\hline-35 & 19.9 & & 2.2 & 2.3 & 1.1 \\
\hline-45 & 17.7 & , & 1.0 & 1.4 & 0.86 \\
\hline $18-A 1-25$ & 20.4 & & 0.7 & 0.7 & 1.1 \\
\hline-35 & 18.2 & & 1.5 & 1.9 & 0.93 \\
\hline \multirow[t]{2}{*}{-45} & 15.8 & : & 1.2 & 1.2 & 1.2 \\
\hline & & & & Average $\rightarrow$ & 1.05 \\
\hline Frit 18 & 22.7 & & 4.0 & 4.5 & - \\
\hline Frit 21 & 17.8 & & 1.7 & - & - \\
\hline
\end{tabular}


The quantity of $\mathrm{Na}_{2} \mathrm{O} \cdot \mathrm{B}_{2} \mathrm{O}_{3}$ evolved increased exponentially when the mole $\%$ of $\mathrm{Na}$ in the glass melt was increased (Fig. 4a\&b). Measurements were made over a range of $12-23$ mole $\% \mathrm{Na}_{2} \mathrm{O}$ in the glass. Volatility varied from $1.5 \mathrm{mg} / \mathrm{cm}^{2}$ (at 12 mole $\% \mathrm{Na}_{2} 0$ ) to $8.5 \mathrm{mg} / \mathrm{cm}^{2}$ (at 22.7 mole $\% \mathrm{Na}_{2} 0$ ). A linear relationship between the logarithm of total weight loss of the sample and $\mathrm{Na}_{2} \mathrm{O}$ content of the melt was also obtained by Kolykov ${ }^{7}$ when he studied the system $\mathrm{Na}_{2} \mathrm{O}-\mathrm{B}_{2} \mathrm{O}_{3}-\mathrm{SiO}_{2}$. Barlow ${ }^{4}$ confirmed that sodium volatilizes from a borosilicate glass melt as either sodium metaborate or sodium diborate, and that volatility depends on the initial $\mathrm{Na}$ content of the melt.

Electron spectroscopy for chemical analysis (ESCA) showed that the surface of the melts are depleted in $\mathrm{Na}$, but not $\mathrm{Ti}$, as the time of vitrification increases (Table 9).

TABLE 9

Elemental Ratios at Surfaces of Glass Melts as Measured by ESCA

$\begin{array}{ccc}\begin{array}{l}\text { Time } 2250^{\circ} \mathrm{C} \\ \text { hrg }\end{array} & \begin{array}{c}\text { EZemental Ratios } \\ \mathrm{Na} / \mathrm{Si}\end{array} & \text { Ti/Si } \\ 0 & 3.7 & 1.3 \\ 1 & 2.3 & 1.3 \\ 3 & 1.0 & 1.0\end{array}$

Lithium metaborate volatility was about $1 / 10$ that of sodium borate. Changes in melt composition or in melting conditions had no appreciable effect on Li volatility.

The type sludge, the type frit, and the concentration of other components affected volatility only to the extent that changes in these variables changed the mole $\%$ of $\mathrm{Na}_{2} \mathrm{O}$ in the glass me1t.

Cesium

Cesium, which volatilized from the melt elementally or as an oxide, was the most volatile of the three alkali metals studied. An average of $0.11 \mathrm{mg} / \mathrm{cm}^{2}$ of $\mathrm{Cs}\left(\right.$ as $\left.C s_{2} O\right)$ volatilized from samples that contained a range of 0.03 to 0.09 wt $\%$ cesium. All samples were held at the melt temperature of $1150^{\circ} \mathrm{C}$ for 3 hours. Because previous workers have reported that addition of $\mathrm{TiO}_{2}, \mathrm{~B}_{2} \mathrm{O}_{3}$ or $\mathrm{MoO}_{3}$ to glass melts reduced volatility, one part of this work compared Cs volatilization from glass melts prepared from frits containing 0,5 , and $10 \mathrm{wt} \% \mathrm{TiO}_{2}$. A comparison was also made between cesium volatility from melts which contained $\mathrm{Cs}$ as Cs-loaded zeolite or as a $\mathrm{Cs}_{2} \mathrm{CO}_{3}$ solution. 


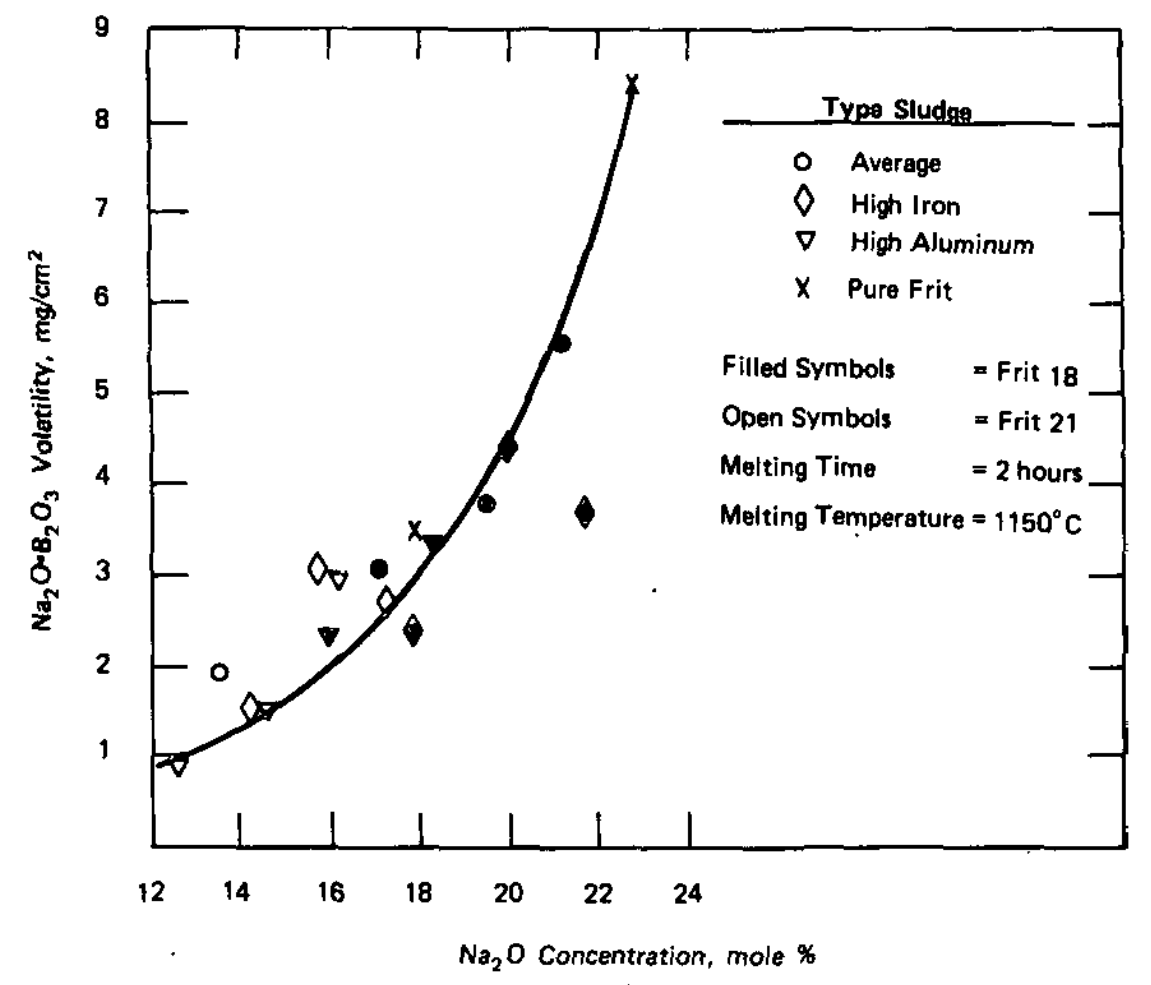

(a)

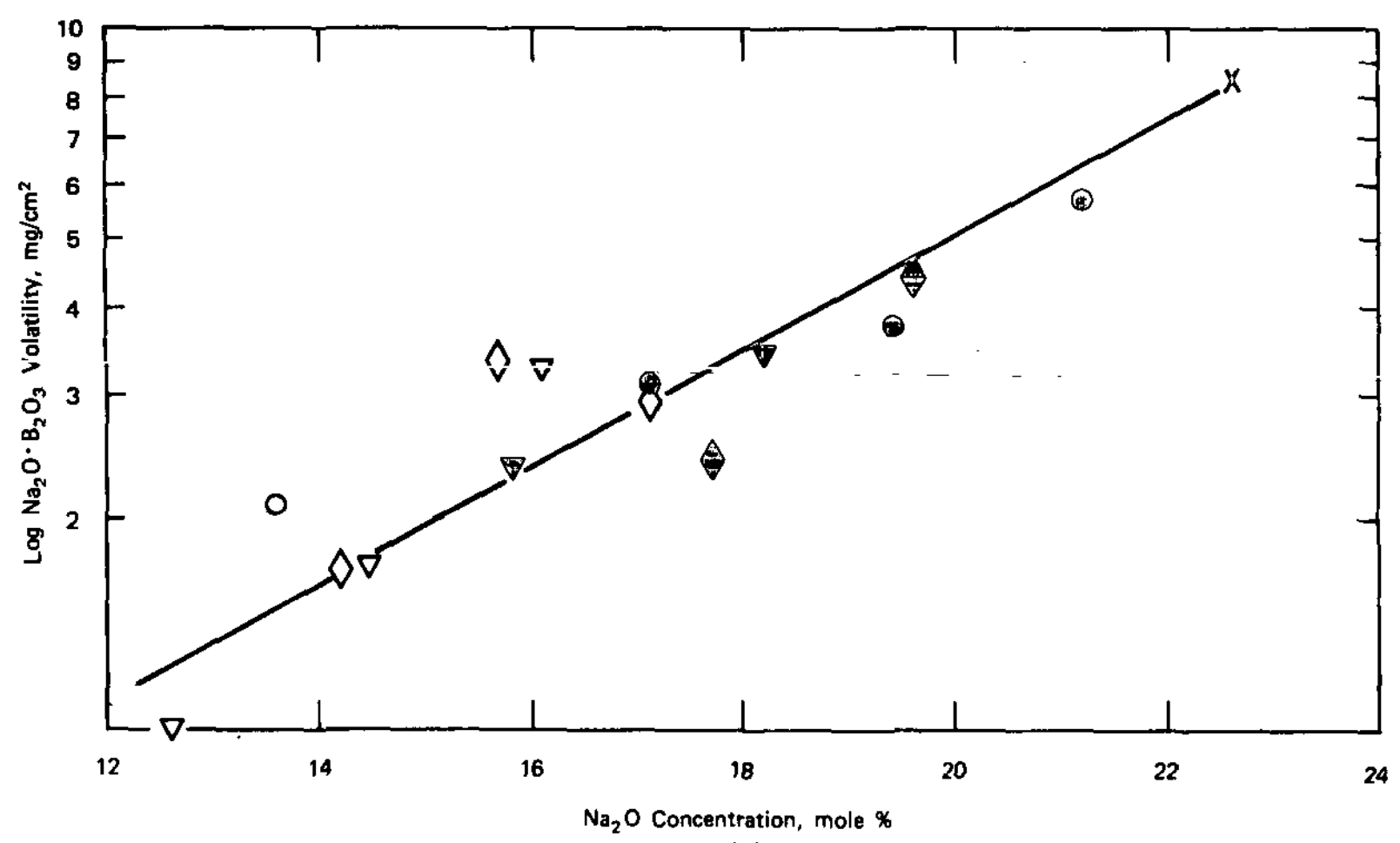

(b)

FIGURE 4. Volatility of $\mathrm{Na}_{2} \mathrm{O} \cdot \mathrm{B}_{2} \mathrm{O}_{3}$ at various $\mathrm{Na}_{2} \mathrm{O}$ Concentrations 
Tables 10-12 summarize the effect of $\mathrm{wt} \% \mathrm{TiO}_{2}$, form of $\mathrm{Cs}$ addition, and concentration of $\mathrm{Cs}$ in the melt on the volatility of Cs. The high per cent volatilities reflect the high surface area to-weight ratios for the small samples used and should not be interpreted as a direct measure of the amount of $C s$ expected to volatilize from a full scale melter. If these levels of volatility are scaled up to a 2.2 ton/day melter they represent volatilization of $0.05 \%$ of the $\mathrm{Cs}$ in the melter charge. Battelle Northwest Laboratories, by comparison, measured $\sim 0.3 \%$ Cs volatility when they vitrified simulated Light Water Reactor (LWR) waste that contained 0.2 wt $\% \mathrm{Cs}_{2} 0 .{ }^{8}$ A melting temperature of $1050^{\circ} \mathrm{C}$ for 6 hours was used in the Battelle study.

The slight suppression of Cs volatility by the addition of $\mathrm{TiO}_{2}$ can be seen by comparing samples in Table 10. The volatility is decreased so slightly that the Cs vaporization encountered during glass melting would not be significantly reduced. The failure of $\mathrm{TiO}_{2}$ to significantly reduce $\mathrm{Cs}$ volatilization is explained by the work of Rastogi, et al. ${ }^{9,10}$ who found that reductions in Cs volatility were obtained only at temperacures below $1000^{\circ} \mathrm{C}$ and for vitrification times $<1$ hour. For example, the model compound $\mathrm{Cs}_{2} \mathrm{O} \cdot 4 \mathrm{TiO}_{2}$ does not volatilize at $400^{\circ} \mathrm{C}$, but $31 \%$ does volatilize at $1200^{\circ} \mathrm{C}$. Rudolph, et $a{ }^{11}$ and Kupfer and Schulz $z^{12}$ report that $\mathrm{TiO}_{2}$ effectively suppresses $\mathrm{Cs}$ volatilization in the $1000-1050^{\circ} \mathrm{C}$ temperature range. The failure of $\mathrm{TiO}_{2}$ to significantly suppress Cs volatility is probably caused by the large amounts of $\mathrm{B}_{2} \mathrm{O}_{3}$ in the melt compositions used for SRP glasses. Rudolph, et al. ${ }^{1}$ found that $\mathrm{B}_{2} \mathrm{O}_{3}$, though not as effective as $\mathrm{TiO}_{2}$, does reduce volatility of $\mathrm{Cs}$. The effect of $\mathrm{TiO}_{2}$ is probably reduced when the melt contains $\mathrm{B}_{2} \mathrm{O}_{3}$ as a constituent.

Incorporation of $\mathrm{Cs}$ into the glass as Cs-loaded zeolite (.02

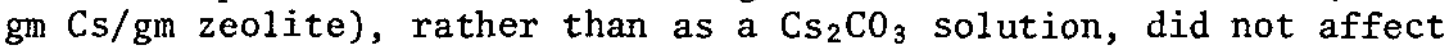
Cs volatility from the glass melt. Table 11 shows that Cs volatility did not depend on the form of Cs addition. Kelley ${ }^{13}$, in his work on radionuclide vaporization from SRP waste, concluded that volatility of $\mathrm{Cs}$ was unchanged when Cs-loaded zeolite was substituted for direct addition of $\mathrm{Cs}_{2} \mathrm{CO}_{3}$.

Total Cs volatility increased when the total amount of Cs in the melt was increased (Table 12). The increase in volatility was proportional to the increased Cs concentration, suggesting that $\mathrm{Cs}$ vaporized by diffusion from the melt surface.

Albrethsen and Schwendiman, ${ }^{14}$ in their work on radionuclide volatility, proposed that Cs volatilizes from glass melts according to:

$$
\mathrm{Cs}_{2} \mathrm{O}_{(\ell)} \rightarrow \mathrm{Cs}(\mathrm{g})+\mathrm{Cs}_{(\mathrm{g})}
$$


The relative amounts of the two gaseous species are dependent on the oxidizing conditions since the reaction,

$$
2 \mathrm{Cs}(\mathrm{g})+\mathrm{O}_{2}(\mathrm{~g})+2 \mathrm{Cs} 0(\mathrm{~g})
$$

occurs in the vapor phase. Though the relative abundance of the gaseous species will vary, the total Cs volatility is probably independent of oxidizing conditions. The Knudsen cell studies did detect elemental $\mathrm{Cs}$ above the melt at a temperature of $1200^{\circ} \mathrm{C}$. No cesium borates were detected.

TABLE 10

Effect of Addition of $\mathrm{TiO}_{2}$ On Cesium Volatility

\begin{tabular}{llcl} 
Cesium & $\mathrm{Cs}_{2} \mathrm{O}$ & $\mathrm{TiO}_{2}$ & \\
Added As & in Glas8, wt $\%$ & in Frit, wt \% & Volatility, $\mathrm{mg} / \mathrm{cm}^{2}$ \\
\cline { 2 - 4 } Zeolite & 0.03 & 0 & 0.08 \\
Zeolite & 0.03 & 10 & 0.06 \\
Carbonate & 0.03 & 0 & 0.08 \\
Carbonate & 0.03 & 10 & 0.06
\end{tabular}

TABLE 11

Effect of Form of Addition on Cesium Volatility

\begin{tabular}{|c|c|c|c|}
\hline $\begin{array}{l}\text { Cesizm } \\
\text { Added As }\end{array}$ & $\begin{array}{l}\mathrm{Cs}_{2} \mathrm{O} \\
\text { in Glass, wt \% }\end{array}$ & $\begin{array}{l}\mathrm{TiO}_{2} \\
\text { in Frit, wt \% }\end{array}$ & $\begin{array}{l}\mathrm{Cs}_{2} \mathrm{O} \\
\text { Volatility, } \mathrm{mg} / \mathrm{cm}^{2}\end{array}$ \\
\hline Zeolite & .03 & 0 & 0.08 \\
\hline Carbonate & .03 & 0 & 0.08 \\
\hline Zeolite & .03 & 10 & 0.06 \\
\hline Cârtunate & .03 & 10 & 0.06 \\
\hline Zeolite & .09 & 10 & 0.10 \\
\hline Carbonate & .09 & 10 & 0.15 \\
\hline
\end{tabular}

TABLE 12

Effect of $\mathrm{Cs}_{2} \mathrm{O}$ Concentration on Cesium Volatility

\begin{tabular}{|c|c|c|}
\hline $\begin{array}{l}\mathrm{Cs}_{2} \mathrm{O} \\
\text { in Glass }\end{array}$ & $\begin{array}{l}\mathrm{TiO}_{2} \\
\text { in Frit, wt \% }\end{array}$ & $\begin{array}{l}\text { Volatility } \\
\mathrm{mg} / \mathrm{cm}^{2}\end{array}$ \\
\hline .03 & 0 & 0.08 \\
\hline .03 & 10 & 0.06 \\
\hline .06 & 5 & 0.11 \\
\hline .06 & 5 & 0.13 \\
\hline .09 & 0 & 0.21 \\
\hline .09 & 10 & 0.15 \\
\hline
\end{tabular}




\section{REFERENCES}

1. J. A. Kelley. Evaluation of Glass as a Matrix for Savannah River Plant Waste: Radioactive Studies. USERDA Report DP-1397, Savannah River Laboratory, E. I. du Pont de Nemours and Co., Aiken, SC (October 1975).

2. J. A. Stone, J. A. Kelley and T. S. McMillan. Scompling and. Analyses of SRP High-Level Waste Sludges. USERDA Report DP-1399, Savannah River Laboratory, E. I. du Pont de Nemours and Co., Aiken, SC (August 1976).

3. J. A. Stone. Separation of SRP Waste Sludge and Supernate. USERDA Report DP-1441, Savannah River Laboratory, E. I. du Pont de Nemours and Co., Aiken, SC (November 1976).

4. D. F. Barlow, "Volatilization of Fluorides, Borates and Arsenic from Glass." VIIth International Congress on Glass, Brusse1s (June 28-July 2, 1965).

5. D. Walmsley, B. A. Sammons and J. R. Grover. Volatility Studies of Glasses for the Fingal Process. AERE-R5777, Atomic Energy Research Establishment, Harwe11, England (July 1969).

6. N. V. Solomon, "Chemical Compounds in Borate Glasses" Structure of Glass Symposizm I, Leningrad (November 23-27, 1953).

7. G. A. Kolykov. "Selective Volatilization of Components of the System $\mathrm{Na}_{2} \mathrm{O}-\mathrm{B}_{2} \mathrm{O}_{3}-\mathrm{SiO}_{2}$ as a Method for Studying the Nature of the Glassy State." Structure of Glass Symposium I, Leningrad (November 23-27, 1953).

8. J. E. Mendel, et al. Annual Report on the Characteristics of High Level Waste Glasses. USERDA Report BNWL-2252, Battelle Pacific Northwest Laboratory, Rich1and, Wash. (June 1977).

9. R. C. Rastogi, J. D. Sehgal and K. T. Thomas. Investigation of Materials and Methods for Fixation of Low and Medium Level Radioactive Waste in Stable Solid Media. BARC-304, Bhabha Atomic Research Center, Bombay, India (1967). 
10. R. C. Rastogi, J. D. Sehgal and K. T. Thomas. Investigation of Materials and Methods for Fixation of Low and Medium Level Radioactive Waste in Stable Media. AEET-250, Atomic Energy Establishment Trombay, Bombay, India (1966).

11. G. Rudolph, et a1. "Lab-Scale RogD Work on Fission Product Solidification by Vitrification on Thermite Processes." Symposium on the Management of Radioactive Wastes from Fuel Reprocessing, KFK-1743, OECD-NEA and IAEA, Paris (November 27December 1, 1972).

12. M. J. Kupfer and W. W. Schulz. Endothermic Process-Application to Immobilization of Hanford In-Tank Solidified Waste, ARH-2800, Atlantic Richfield Hanford Co., Richland, Wash. (July 1973).

13. J. A. Kelley. Evaluation of Glass as a Matrix for Solidification of Savannah River Plant Waste: Nonradioactive and Tracer Studies. USERDA Report DP-1382, Savannah River Laboratory, E. I. du Pont de Nemours and Co., Aiken, SC (May 1975).

14. A. E. Albrethsen and L. C. Schwendiman. Volatilization of Fission Products from High-Level Ceramic Wastes. USAEC Report BNWL-338, Battelle Pacific Northwest Laboratory, Richland, Wash. (February 1967). 